\title{
Myxomycetes appearing in moist chamber cultures on samples of bark and wood collected from coarse woody debris
}

\section{Massingill JM and Stephenson SL}

Department of Biological Sciences, University of Arkansas, Fayetteville, Arkansas 72701 Email: jmassing@uark.edu, slsteph@uark.edu

Massingill JM, Stephenson SL 2013 - Myxomycetes appearing in moist chamber cultures on samples of bark and wood collected from coarse woody debris. Mycosphere 4(3), 627-633, Doi $10.5943 /$ mycosphere/4/3/14

\begin{abstract}
The species associated with coarse woody debris make up the best known ecological assemblage of myxomycetes, but most records are based on fruiting bodies that have formed in the field under natural conditions and not from samples of bark and wood placed in moist chamber cultures. In this study, samples of bark and wood from pieces of coarse woody debris on the forest floor were collected and used to prepare a series moist chamber cultures. All of the 30 cultures prepared with wood and 29 of the 30 (97\%) of the cultures prepared with bark were positive for myxomycetes. Thirty-three different species representing 14 genera were recovered, with 21 species (14 genera) recorded for bark and 22 species (11 genera) recorded for wood. These data indicate that any effort to carry out a truly comprehensive survey of the myxomycetes present at a given locality should include examining samples of coarse woody debris with the moist chamber culture technique.
\end{abstract}

Key words - Devil's Den State Park - ecological study - moist chamber cultures - slime moulds

\section{Introduction}

The myxomycetes (also called plasmodial slime moulds or myxogastrids) are a group of fungus-like organisms usually present and sometimes abundant in terrestrial ecosystems (Martin \& Alexopoulos 1969, Stephenson 2003). In fact, at least some representatives of the group have been recorded from virtually every type of ecosystem examined to date. Myxomycetes are characterized by a life cycle that involves two trophic stages-one consisting of microscopic uninucleate amoeboflagellate cells and the other of a multinucleate plasmodium - along with a reproductive stage (fruiting body or sporocarp) somewhat similar to the spore-producing fruiting bodies of certain macrofungi, albeit much smaller (Stephenson \& Stempen 1994, Stephenson 2011).

In temperate forests, myxomycetes are known to occur on decaying coarse woody debris on the forest floor, the bark surface of living trees, forest floor litter, the dung of herbivorous animals, soil, and aerial litter (portions of dead but still standing herbaceous plants). Each of these microhabitats (or substrates) supports a different assemblage of species (Stephenson 1988, 1989; Stephenson \& Stempen 1994). The myxomycetes associated with coarse woody debris are the best known, since the species typically occurring in this microhabitat tend to be among those characteristically producing fruiting bodies of sufficient size to be detected easily in the field (Martin \& Alexopoulos 1969). Much less is known about the myxomycetes associated with the 
microhabitats represented by the bark surface of living trees, forest floor litter, aerial litter and soil. The primary reason for this is that many of the species involved are rather inconspicuous or sporadic in their occurrence and thus difficult to detect in the field. However, the moist chamber culture technique as it applies to myxomycetes (Gilbert \& Martin 1933) provides a convenient and often very productive method of supplementing field collections when studying such microhabitats as those listed above. Since its introduction, the technique has been used with considerable success by numerous researchers (e.g., Keller \& Brooks 1976; Härkönen 1981; Blackwell \& Gilbertson 1980; Stephenson 1989; Wrigley de Basanta et al. 2010, 2013; Lado et al. 2011, 2013). The use of moist chamber cultures in studying myxomycetes is described in some detail by Stephenson \& Stempen (1994).

The vast majority of records of myxomycetes associated with coarse woody debris have been based on fruiting bodies that have formed in the field under natural conditions and not from samples of bark and wood placed in moist chamber cultures. Obtaining such samples is not a standard component of biodiversity surveys for myxomycetes. As such, the question might be asked as to whether or not field collections alone truly reflect the total species composition of the myxomycetes associated with coarse woody debris. The study described herein was carried out to determine just what species of myxomycetes could be recovered in moist chamber cultures on samples taken directly from pieces of coarse woody debris occurring on the forest floor.

\section{Methods}

The samples considered in the present study were collected from an oak-hickory (QuercusCarya) forest in Devil's Den State Park (35 $46^{\prime} 26$ N and 94 $14^{\prime} 23 \mathrm{~W}$ ) in northwest Arkansas during August 2012. Samples of bark and the underlying wood were obtained from ten different decaying logs located at various places on the forest floor (Fig. 1). To prevent cross contamination, each sample of bark or wood was placed individually into a small plastic bag and brought to the laboratory of the second author at the University of Arkansas. Because moisture builds up in a sealed plastic bag, all sample material was removed from the bags within a day. Samples of bark and wood were placed on sterile pieces of paper where they could be cut or broken up into smaller pieces that would fit within the $15 \mathrm{~cm}$ plastic disposable Petri dishes used to prepare what

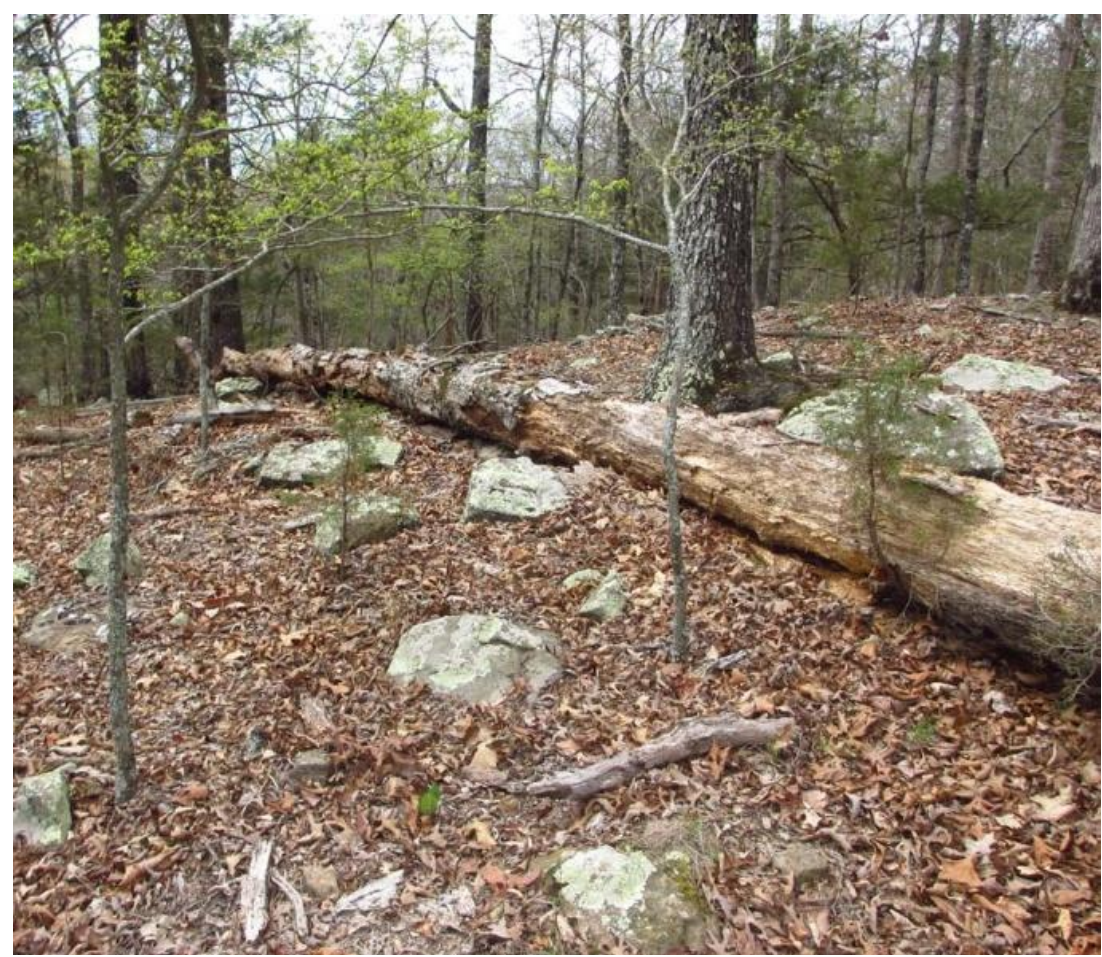

Fig. 1 - Coarse woody debris on the forest floor at Devil's Den State Park in Arkansas. 
were to become moist chamber cultures. The bottom of each Petri dish was lined with a piece of filter paper, and enough sample material was placed in the dish to cover the bottom as completely as possible yet still allowing a lid to be placed on the dish. Three different plates were prepared from the bark samples collected from each of the ten logs and the same procedure was followed for the samples of wood. This yielded a total of 60 plates. Each plate was then filled with enough distilled water to cover most of the sample material and what was now a moist chamber culture left undisturbed overnight. The following day, the $\mathrm{pH}$ of the water in each plate was determined with a portable $\mathrm{pH}$ meter, this value recorded, and most of the water remaining in the plate was poured out.

The 60 moist chamber cultures were maintained under ambient conditions (ca $23^{\circ} \mathrm{C}$ ) and in diffuse light for the period of the study. Each week, they were checked under a dissecting microscope for evidence (either plasmodia or fruiting bodies) of myxomycetes, and a small amount of water was added to any culture that seemed to be drying out. When the fruiting bodies of a myxomycete were noticed, the portion of the wood or bark upon which they occurred was removed, glued to a small paper tray, and the latter mounted in a pasteboard box for permanent storage. All occurrences of the same species in a single moist chamber culture were considered to represent one record. Identifications were made with the use of standard monographs. Nomenclature used herein essentially follows Lado (2005-2013) except for Stemonitis nigrescens, where the treatment used is that of Martin \& Alexopoulos (1969). Voucher specimens of all species are deposited in the herbarium of the University of Arkansas (UARK).

The two sets of data were compared using coefficient of community and percentage similarity indices (Mueller-Dombois \& Ellenberg 1974, Gauch 1982). The equation for the former, which is based solely on a consideration of the presence or absence of species, is coefficient of community $(\mathrm{CC})=2 \mathrm{c} /(\mathrm{a}+\mathrm{b})$ where $a$ is the total number of species in the first community (or assemblage) being considered, $b$ is the total number of species in the second community, and $c$ is the number of species shared in common. The value of CC ranges from 0 when no species are present in both communities to 1.0 when all species are present in both communities.

The equation for percentage similarity, which considers the relative abundance of species in a community and not just their presence, is percentage similarity (PS) $=\Sigma \min (\mathrm{a}, \mathrm{b}, \ldots \mathrm{x}$ ) where $\min$ is the lesser of the two percentage composition values of species $a, b, \ldots . x$ in the two communities. The value of PS ranges from 0 for communities with no species in common to 1.0 for communities identical both in species composition and quantitative values for the species.

In addition, species diversity indices were calculated for each set of data by using Shannon's formula (Shannon \& Weaver 1963), which is species diversity $\left(\mathrm{H}^{\prime}\right)=-\Sigma \mathrm{Pi} \log \mathrm{Pi}$ where $P i$ is the proportion of the total number of individuals represented by species $i$. This index varies from a value of 0 for a community containing a single species to some maximum value for a community containing many species, each represented by a small number of individuals.

\section{Results}

All of the 30 moist chamber cultures prepared with wood and 29 of the $30(97 \%)$ cultures prepared with bark were positive for myxomycetes (Fig. 2). Thirty-three different species representing 14 genera were recovered, with 21 species in 14 genera recorded for bark and 22 species in 11 genera recorded for wood (Table 1). This total included one specimen (Comatricha sp. A) that could be identified only to genus but which was clearly distinct from the other species in same genus recovered in the present study. Seven cultures prepared with wood yielded four or more species, whereas at least four species were recorded from 12 cultures prepared with bark. The average number of species recorded per moist chamber culture was 2.4 for wood and 3.3 for bark. These figures reflect the overall pattern of occurrence on the two different substrates, with a higher number of records from bark (98) than from wood (74).

A number of species were restricted largely or completely to either bark or wood (Table 1), although the species (Metatrichia vesparia) represented by the highest number of collections was almost equally abundant on the two different substrates. For species recorded on at least three 


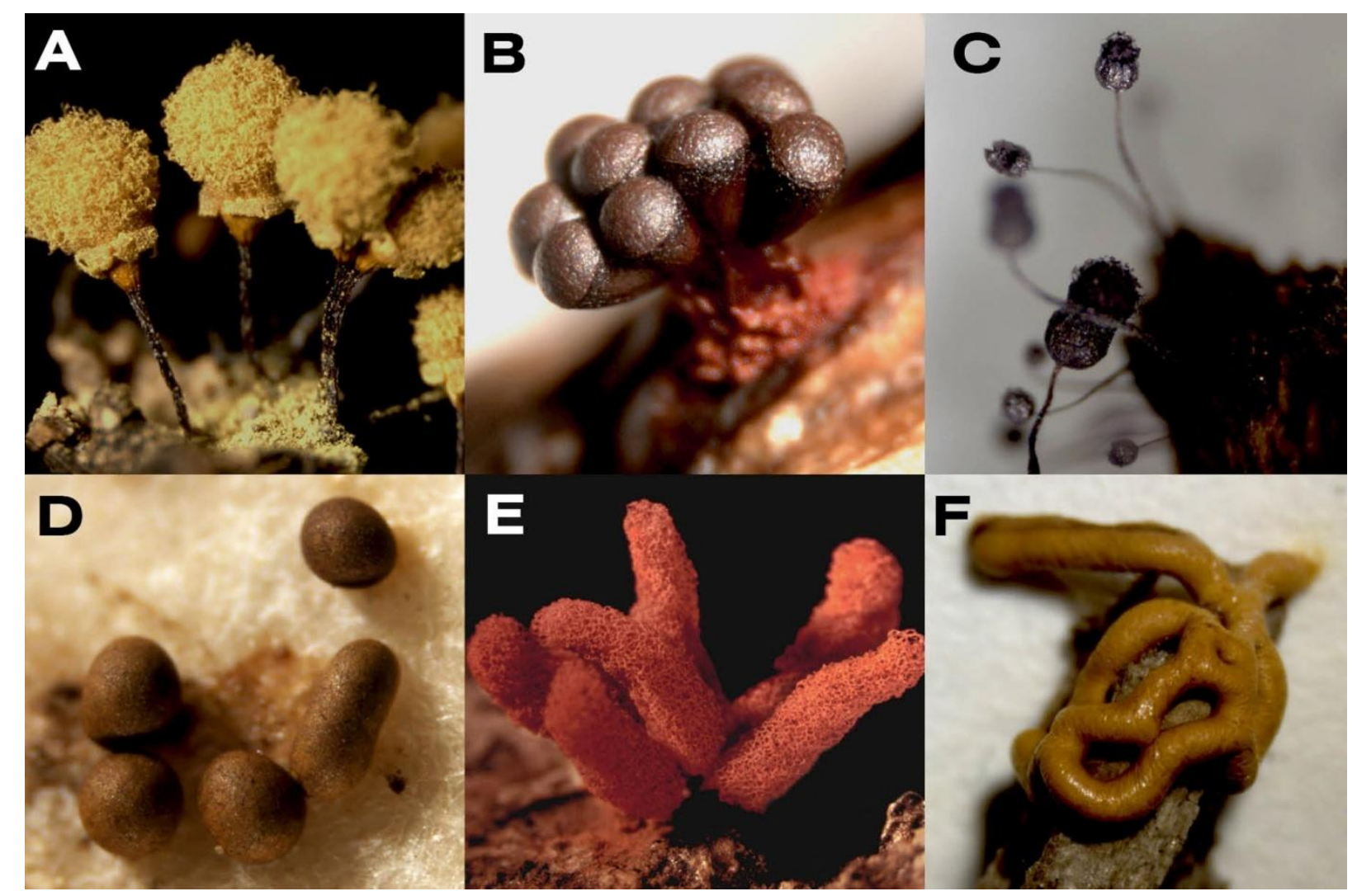

Fig. 2 - Examples of myxomycetes recorded in moist chamber cultures on samples of coarse woody debris. A. Hemitrichia calyculata. B. Metatrichia vesparia. C. Cribraria violacea. D. Perichaena chrysosperma. E. Arcyria denudata. F. Hemitrichia serpula.

occasions, Perichaena chrysosperma, Stemonitis nigrescens, Collaria arcyrionema, Badhamia affinis, Physarum crateriforme, Diderma chondrioderma and Perichaena pedata displayed a clear preference for bark, whereas Comatricha tenerrima, Cribraria microcarpa and Hemitrichia serpula were recorded only from wood. Wood also yielded most of the collections of Arcyria cinerea.

The habitat descriptions usually included in monographic treatments of the myxomycetes (e.g., Martin \& Alexopoulos 1969) often make little or no distinction between decorticated wood and wood with bark still intact when referring to species associated with woody substrates. However, the physical and chemical properties of wood and bark are quite different (Stephenson 1988). For example, differences exist as to the predominant structural polysaccharides (lignin for wood and suberin for bark) present in the two substrates. Moreover, bark typically contains higher concentrations of potentially allelopathic substances (e.g., tannins and phenols) than wood (Swift \& Boddy 1984, Hudson 1986). In addition, the very presence of bark (which usually denotes a relatively early stage of decomposition) affects the microclimate (e.g., aeration, temperature and moisture content) of the underlying wood. Presumably, these factors would be of sufficient magnitude to account for the differences observed in the assemblages of myxomycetes associated with bark and wood. Whether the myxomycetes are responding to differences in their prey organisms (primarily bacteria) or more directly to the physical and chemical characteristics of the substrate itself is not known. In fact, it seems likely that their response is a product of a number of factors. Interestingly, the mean $\mathrm{pH}$ of cultures prepared with samples of bark was 7.2, whereas the mean $\mathrm{pH}$ of cultures prepared with wood was appreciably lower (5.1).

Mean values of $\mathrm{pH}$ recorded for particular species (only species represented by $\geq 3$ collections were considered) ranged from 7.4 for Perichaena pedata to 5.0 for Cribraria microcarpa. As a general observation, all members of the order Physarales (e.g., Badhamia affinis 
Table 1 Occurrence of myxomycetes (data are numbers of records) in moist chamber cultures prepared with samples of bark and wood.

\begin{tabular}{|c|c|c|c|}
\hline Species & Total & Bark & Wood \\
\hline $\begin{array}{l}\text { Metatrichia vesparia (Batsch) Nann.-Bremek. ex G.W. Martin } \\
\text { \& Alexop. }\end{array}$ & 44 & 20 & 24 \\
\hline Perichaena chrysosperma (Curr.) Lister & 28 & 24 & 4 \\
\hline Arcyria cinerea (Bull.) Pers. & 15 & 2 & 13 \\
\hline Cribraria violacea $\operatorname{Rex}$ & 9 & 6 & 3 \\
\hline Stemonitis nigrescens $\mathrm{Rex}$ & 8 & 7 & 1 \\
\hline Collaria arcyrionema (Rostaf.) Nann.-Bremek. ex Lado & 7 & 6 & 1 \\
\hline Trichia favoginea (Batsch) Pers. & 6 & 4 & 2 \\
\hline Physarum crateriforme Petch & 5 & 5 & 0 \\
\hline Comatricha tenerrima (M.A. Curtis) G. Lister & 4 & 0 & 4 \\
\hline Badhamia affinis Rostaf. & 4 & 4 & 0 \\
\hline Hemitrichia calyculata (Speg.) M.L. Farr & 4 & 1 & 3 \\
\hline Physarum decipiens M.A. Curtis & 4 & 4 & 0 \\
\hline Arcyria denudata (L.) Wettst. & 3 & 1 & 2 \\
\hline Cribraria microcarpa (Schrad.) Pers. & 3 & 0 & 3 \\
\hline Diderma chondrioderma (de Bary \& Rostaf.) G. Lister & 3 & 3 & 0 \\
\hline Hemitrichia serpula (Scop.) Rostaf. ex Lister & 3 & 0 & 3 \\
\hline Perichaena pedata (Lister \& G. Lister) Lister ex E. Jahn & 3 & 3 & 0 \\
\hline Hemitrichia pardina (Minakata) Ing & 2 & 2 & 0 \\
\hline Physarum pusillum (Berk. \& M.A. Curtis) G. Lister & 2 & 1 & 1 \\
\hline Trichia lutescens (Lister) Lister & 2 & 0 & 2 \\
\hline Arcyria pomiformis (Leers) Rostaf. & 1 & 0 & 1 \\
\hline Badhamia capsulifera (Bull.) Berk. & 1 & 1 & 0 \\
\hline Comatricha laxa Rostaf. & 1 & 1 & 0 \\
\hline Comatricha nigra (Pers. ex J.F. Gmel.) J. Schrot. & 1 & 0 & 1 \\
\hline Comatricha lurida (Lister) Nann.-Bremek. & 1 & 0 & 1 \\
\hline Comatricha pulchella (C. Bab.) Rostaf. & 1 & 0 & 1 \\
\hline Comatricha sp. A & 1 & 0 & 1 \\
\hline Hemitrichia minor G. Lister & 1 & 0 & 1 \\
\hline Lamproderma scintillans (Berk. \& Broome) Morgan & 1 & 1 & 0 \\
\hline Licea belmontiana Nann.-Bremek. & 1 & 0 & 1 \\
\hline Perichaena vermicularis (Schwein.) Rostaf. & 1 & 1 & 0 \\
\hline Physarum nudum T. Macbr. in Peck \& Gilbert & 1 & 1 & 0 \\
\hline Stemonitis herbatica Peck & 1 & 0 & 1 \\
\hline Total & 172 & 98 & 74 \\
\hline
\end{tabular}

and Diderma chondrioderma) were recorded from cultures with a mean $\mathrm{pH} \geq 6.8$, whereas with a single exception, member of the order Trichiales (e.g., Hemitrichia calyculata and $H$. serpula) were recorded from cultures with a mean $\mathrm{pH} \leq 6.5$ (Table 2 ).

\section{Discussion}

The data obtained in the present study clearly indicate that samples of coarse woody debris placed in moist chamber cultures yield the fruiting bodies of myxomycetes. Moreover, the assemblages of myxomycetes associated with the two different microhabitats (bark and wood) that together make up coarse woody debris are compositionally distinct. For example, coefficient of community and percentage similarity indices calculated from the two sets of data were 0.47 and 0.36 , respectively. Only 10 species were recorded from both microhabitats, but Shannon's diversity indices were relatively close (2.49 for wood and 2.44 for bark).

Since the species associated with coarse woody debris do represent the best known ecological assemblage of myxomycetes, anyone who goes out to collect the fruiting bodies of these organisms tends to look first at woody substrates. Many of the more familiar species in such genera 
Table 2 Occurrence of myxomycetes in relation to the $\mathrm{pH}$ of the moist chamber cultures in which a particular species was recorded. Only species represented by $\geq 3$ records are listed.

\begin{tabular}{|c|c|c|}
\hline \multirow[b]{2}{*}{ Species } & \multicolumn{2}{|c|}{$\mathbf{p H}$} \\
\hline & Mean & Range \\
\hline Perichaena pedata & 7.4 & 7.1 to 7.6 \\
\hline Badhamia affinis & 7.2 & 7.1 to 7.5 \\
\hline Cribraria violacea & 7.0 & 6.5 to 7.4 \\
\hline Diderma chondrioderma & 7.0 & 6.4 to 7.5 \\
\hline Physarum decipiens & 6.9 & 6.7 to 7.1 \\
\hline Collaria arcyrionema & 6.8 & 6.4 to 7.3 \\
\hline Comatricha tenerrima & 6.8 & 5.3 to 7.3 \\
\hline Physarum crateriforme & 6.8 & 6.4 to 7.5 \\
\hline Metatrichia vesparia & 6.5 & 4.7 to 7.5 \\
\hline Trichia favoginea & 6.5 & 6.1 to 7.1 \\
\hline Arcyria cinerea & 6.3 & 4.7 to 7.1 \\
\hline Stemonitis nigrescens & 6.2 & 5.3 to 7.5 \\
\hline Hemitrichia calyculata & 5.9 & 5.3 to 6.9 \\
\hline Hemitrichia serpula & 5.8 & 5.8 to 6.2 \\
\hline Arcyria denudata & 5.7 & 5.4 to 6.9 \\
\hline Perichaena chrysosperma & 5.7 & 4.7 to 7.6 \\
\hline Cribraria microcarpa & 5.0 & 4.8 to 5.6 \\
\hline
\end{tabular}

as Stemonitis and Trichia are invariably associated with bark and wood (Stephenson \& Stempen 1994). However, most records of myxomycetes from woody substrates are based on fruiting bodies that have formed in the field under natural conditions and not from samples of bark and wood placed in moist chamber cultures. There appear to be very few studies reported in the literature in which the latter technique was used to investigate the occurrence of myxomycetes on coarse woody debris. Although many of the species one might expect to record as field collections from coarse woody debris, based on the data reported in other studies (e.g., Stephenson 1988), also appear in moist chamber cultures, these cultures also yield an appreciable number of other species (e.g., Cribraria violacea, C. microcarpa and Perichaena pedata) that produce fruiting bodies too small to be observed easily in the field.

As such, the results obtained in the present study indicate that any effect to carry out a truly comprehensive survey of the myxomycetes present at a given locality should include examining samples of coarse woody debris with the moist chamber culture technique. This would be done in the same manner as the samples usually collected from such microhabitats as the forest floor litter layer and the bark surface of living trees.

\section{References}

Blackwell M, Gilbertson RL. 1980 - Sonoran desert myxomycetes. Mycotaxon 11, 139-149.

Gauch HG Jr. 1982 - Multivariate analysis in community ecology. Cambridge University Press, Cambridge.

Gilbert HC, Martin GW. 1933 - Myxomycetes found on the bark of living trees. University of Iowa Studies in Natural History 15, 3-8.

Härkönen M. 1981 - Myxomycetes developed on litter of common Finnish trees in moist chamber cultures. Nordic Journal of Botany 1, 791-794.

Hudson HJ. 1986 - Fungal biology. Edward Arnold, Baltimore, Maryland.

Keller HW, Brooks TE. 1976 - Corticolous myxomycetes V: observations on the genus Echinostelium. Mycologia 68, 1204-1220.

Lado C. 2005-2013 - An online nomenclatural information system of Eumycetozoa. http://www.nomen.eumycetozoa.com (accessed on May 15, 2013).

Lado C, Wrigley de Basanta D, Estrada-Torres A. 2011 - Biodiversity of myxomycetes from the 
Monte Desert of Argentina. Anales del Jardin Botánico de Madrid 68, 61-95.

Lado C, Wrigley de Basanta D, Estrada-Torres A, Stephenson SL. 2013 - The biodiversity of myxomycetes in central Chile. Fungal Diversity 59, 3-32.

Martin GW, Alexopoulos CJ. 1969 - The myxomycetes. University of Iowa Press, Iowa City.

Mueller-Dombois D, Ellenberg H. 1974 - Aims and methods of vegetation ecology. John Wiley and Sons, New York.

Shannon CE, Weaver W. 1963 - The mathematical theory of communication. University of Illinois Press, Irbana, Illinois.

Stephenson SL. 1988 - Distribution and ecology of myxomycetes in temperate forests. I. Patterns of occurrence in the upland forests of southwestern Virginia. Canadian Journal of Botany 66, 2187-2207.

Stephenson SL. 1989 - Distribution and ecology of myxomycetes in temperate forests. II. Patterns of occurrence on bark surface of living trees, leaf litter, and dung. Mycologia 81, 608-621.

Stephenson SL. 2003 - Myxomycetes of New Zealand. Fungal Diversity Press, Hong Kong.

Stephenson SL. 2011 - From morphological to molecular: studies of myxomycetes since the publication of the Martin and Alexopoulos (1969) monograph. Fungal Diversity 50, 21-34.

Stephenson SL, Stempen H. 1994 - Myxomycetes: a handbook of slime molds. Timber Press, Portland, Oregon.

Swift MJ, Boddy L. 1984 - Animal-microbial interactions in wood decomposition. In: Invertebratemicrobial interactions. (Anderson JM, Rayner ADM, and Walton DWH, eds.) Pp. 89-131. Cambridge University Press, Cambridge.

Wrigley de Basanta D, Lado C, Estrada-Torres A, Stephenson SL. 2010 - Biodiversity of myxomycetes in subantarctic forests of Patagonia and Tierra del Fuego, Argentina. Nova Hedwigia 90, 45-79.

Wrigley de Basanta D, Lado C, Estrada-Torres A, Stephenson SL. 2013 - Biodiversity studies of myxomycetes in Madagascar. Fungal Diversity 59, 55-83. 